\title{
Molecular genetic aspects and pathophysiology of endocrine hypertension
}

\author{
Stelios Fountoulakis, Agathocles Tsatsoulis
}

Department of Endocrinology, University of Ioannina Medical School, Ioannina, Greece

\section{INTRODUCTION}

Blood pressure (BP) is the outcome of the interaction of intravascular volume, cardiac output and peripheral resistance. Hypertension is defined as BP exceeding 139/89 mmHg, whereas "pre-hypertension" refers to systolic BP of 120 to $139 \mathrm{mmHg}$ or a diastolic BP of 80 to $89 \mathrm{mmHg}$. Traditionally, hypertension has been subdivided into two forms: essential or primary and secondary. Essential hypertension is a term applying to cases in which no cause can be identified (idiopathic) and accounts for approximately $85 \%$ of hypertensive patients.

Secondary hypertension, on the other hand, denotes BP elevation that results from an underlying identifiable cause. About $15 \%$ of hypertensive patients are identified as having secondary hypertension. Recently, the notion that secondary hyperten-

Key words: Acromegaly, Aldosteronism, Cushing's syndrome, Hyperparathyroidism, Hyperthyroidism, Hypothyroidism, Pheochromocytoma, Secondary hypertension.

Address correspondence and requests for reprints to: Agathocles Tsatsoulis, MD, PhD, FRCP, Professor of Medicine-Endocrinology, Division of Endocrinology, Department of Medicine, University of Ioannina, Ioannina 45110, Greece, Tel.: +30-2651-0-97500, Fax: +30-2651-0-97016, E-mail: atsatsou@uoi.gr Received 31-10-05, Revised 12-01-06, Accepted 10-02-06 sion is rare has been challenged by the suggestion that primary aldosteronism, originally thought to be present in about $1 \%$ of individuals with hypertension, is present in up to $15 \%$ of hypertensives with a mean age of $54.1 \pm 11.2$ years. ${ }^{1,2}$ Endocrine hypertension is characterized by hormonal derangements that result in secondary hypertension. Its most common causes are excessive production of mineralocorticoids, catecholamines and glucocorticoids. Others include growth hormone excess, parathyroid hormone (PTH) excess and excess or deficiency of thyroid hormones production.

This review will focus on the pathophysiologic mechanisms by which hormone excess results in hypertension and will provide new molecular genetic data on disorders leading to endocrine hypertension.

\section{MINERALOCORTICOID EXCESS - PRIMARY HYPERALDOSTERONISM}

Primary hyperaldosteronism (PA) is characterized by aldosterone overproduction and concomitant suppression of the angiotensin-renin system, independent of angiotensin II (Ang II). Its main features include hypertension and altered potassium homeostasis. Numerous studies have recently reported a marked increase in its prevalence due to the wider use of the plasma aldosterone to plasma renin activity ratio (ARR) as a screening and diagnostic test. PA is currently considered to be the most common form of secondary hypertension affecting $5-15 \%$ of all hypertensives. ${ }^{2-6}$ ARR leads to the recognition 
of milder clinical forms of PA, mainly caused either by idiopathic bilateral adrenal hyperplasia (approximately two thirds of all cases), ${ }^{7}$ or microadenomas, with normokalemia and clinically indistinguishable from essential hypertension. PA prevalence approaches $20 \%$ in patients with resistant hypertension. ${ }^{8}$

The most common subtypes of PA are idiopathic bilateral hyperplasia (IBH) ( $65 \%$ of cases) and aldosterone-producing adenoma (APA) ( 30\%). Unilateral adrenocortical adenoma is also known as Conn's syndrome. Minor causes include unilateral hyperplasia or primary adrenal hyperplasia $(\mathrm{PAH})(\sim 3 \%)$, aldosterone producing adrenocortical carcinoma $(<1 \%)$ and familial varieties $(<1 \%)$. Two forms of familial hyperaldosteronism (FH) have been described: FH type I (FH-I) and FH type II (FH-II). FH-I, or glucocorticoid-remediable aldosteronism (GRA), is autosomal dominant in inheritance and is associated with variable degrees of adrenocorticotropin hormone (ACTH)-dependent hyperaldosteronism, renin suppression and high levels of hybrid steroids, ${ }^{9}$ while hypokalemia is uncommon. ${ }^{10} \mathrm{FH}$ type II is more common than FH-I and refers to the familial occurrence of APA, IBH or both. ${ }^{11}$ The underlying genetic basis for FH-I is well defined so that diagnosis can be reached by the use of genetic testing. For FH-II, the search for responsible gene mutations has not reached definite conclusions.

\section{FH-I}

Aldosterone, the principal human mineralocorticoid, is produced in the zona glomerulosa by aldosterone synthase (AS) after sequential 11 $\beta$-hydroxylation, 18-hydroxylation and 18-oxidation of deoxycorticosterone (DOC). ${ }^{12}$ AS is encoded by the $C Y P 11 B 2$ gene that is located on chromosome $8 \mathrm{q} 24.3$, in tandem with the highly homologous CYP11B1 gene, which encodes $11-\beta$-hydroxylase. ${ }^{13}$ The latter enzyme acts in the zona fasciculata to convert 11-deoxycortisol to cortisol, but is devoid of 18-hydroxylation and 18-oxidation activities. $C Y P 11 B 1$ is widely expressed at high levels throughout the adrenal cortex, with ACTH as its main positive regulator. Conversely, $C Y P 11 B 2$ is selectively expressed in the zona glomerulosa and is primarily regulated by serum potassium and Ang II levels. Both CYP11B2 mRNA and AS activity have also been detected in various tissues, including the heart, the vessels, the brain and lymphocytes.

The genetic defect leading to FH-I was described in 1992. ${ }^{9}$ It is the result of unequal recombination between $C Y P 11 B 1$ and $C Y P 11 B 2$. This generates a chimeric (hybrid) $C Y P 11 B$ gene containing $C Y P 11 B 1$ sequences at its 5 ' end and $C Y P 11 B 2$ sequences at its 3' end. ${ }^{9}, 14$ Therefore, the hybrid gene encodes an enzyme that synthesizes excessive amounts of aldosterone throughout the adrenal cortex but, unlike $C Y P 11 B 2$, is ACTH- rather than AngII-dependent under the control of the 5' $C Y P 11 B 1$ regulatory elements, and therefore glucocorticoid suppressible. Moreover, the 18-hydroxylation and 18-oxidation of cortisol generates the hybrid steroids $18 \mathrm{OH}$ - and 18oxo-cortisol, which can be detected at high levels in affected patients.

\section{FH-II}

FH-II is clinically and biochemically indistinguishable from the more common Conn's syndrome. ${ }^{15,16}$ Its diagnosis requires PA to be confirmed biochemically in more than two family members. ${ }^{11,15,17} \mathrm{FH}-\mathrm{II}$ is not associated with the hybrid gene mutation. Mutations in the coding region of $C Y P 11 B 2$, in the gene encoding the Ang II type I receptor $(A T 1)$ and $p 53$, were not found in $\mathrm{FH}$ II. ${ }^{11,18,19}$ Linkage analyses have excluded the involvement of several genes including CYP11B2, the $A T 1$ gene and the $M E N 1$ locus, but a recent genome-wide search identified a locus on chromosome $7 \mathrm{p} 22 .{ }^{20,21}$ The best candidate among genes located in this region is PRKAR1B, being a functional partner of $P R K A R 1 A$, which encodes the regulatory subunit type $1 \mathrm{~A}$ of protein kinase A. However, PRKAR1B was recently excluded as a candidate gene for $\mathrm{FH}$ II. ${ }^{22}$

\section{APA-IBH}

Sporadic PA might originate from one or more gene variants. The presence of the chimeric gene has been ruled out in APAs, no point mutations of 
the $C Y P 11 B 1$ gene in the two regions examined were found and no mutations have yet been identified in genes coding for $p 53, R A S$, Gsa, renin, AT1, CYP21 and the MEN1 locus. ${ }^{22-25}$ Conversely, gene expression assays have shown that APAs over-express several genes including renin, $C Y P 21$ and $C Y P 11 B 2 .{ }^{26}$ In studies of IBH patients, germline variants of $C Y P 11 B 2$ and the chimeric $C Y P 11 B 1 / B 2$ gene were not detected. ${ }^{27}$

\section{Mechanisms of hypertension in $P A$}

Aldosterone production is regulated by ACTH, Ang II and plasma potassium. Ang II stimulates aldosterone secretion in response to sodium depletion and reduced extracellular fluid volume, while increased plasma potassium also acts as a powerful stimulus. In PA excessive aldosterone production results in concomitant suppression of the renin and Ang II. Aldosterone affects BP regulation mainly by plasma volume expansion and increase in cardiac output. Aldosterone binding to the mineralocorticoid receptor (MR) creates a complex that leads to the induction of gene products called aldosterone induced proteins (AIPs). ${ }^{29}$ AIPs bind to DNA regulatory elements and may have effects on the apical membrane, the cellular energy production and/or the basolateral $\mathrm{Na}^{+} / \mathrm{K}^{+}$-ATPase pump, resulting in increased sodium reabsorption and potassium and hydrogen ion excretion. ${ }^{29}$ Major sites of these actions are luminal cells of the cortical collecting renal tubules and the distal convoluted tubules. ${ }^{30}$ Apically located epithelial sodium channel $(\mathrm{ENaC})$ is the major determinant of renal sodium reabsorption. ${ }^{30}$ Aldosterone activates serum glucocorticoid regulated kinase (sgk), an AIP which increases $\mathrm{ENaC}$ activity by raising the number of channels at the cell surface..$^{31,32}$

Other mechanisms, apart from volume expansion, are also likely to exist. For example, activation of the MR in vascular smooth muscle cells (VSMC) results in alteration in pressor responsiveness to adrenergic stimulation. Moreover, excessive levels of aldosterone binding to the MR in cardiac and vascular tissue are thought to regulate collagen formation, promotion of cardiac and vascular hypertrophy, remodeling and fibrosis independently of BP elevation. ${ }^{33}$ Indeed, patients with PA exhibit more severe left ventricular hypertrophy (LVH) than patients with essential hypertension. ${ }^{34}$ Such actions in peripheral blood vessels might result in vascular remodeling, which could sustain an elevated BP. The remodeling effects of aldosterone result from activation of NADPH oxidase, stimulation of xanthine oxidase and mitochondrial reactive oxygen species (ROS) generation. ${ }^{35}$ Inflammation may also activate the renin-angiotensin-aldosterone system (RAAS) and contribute to vascular remodeling, but it is unclear whether aldosterone is associated with the inflammatory response found in hypertension. ${ }^{36}$

Finally, an interesting hypothesis linking $11 \beta$ hydroxylase activity and hypertension with PA was recently put forward based on association studies regarding the $C Y P 11 B 2$ gene. ${ }^{37}$ Two common polymorphisms within the $C Y P 11 B 2$ gene have been described that are in linkage disequilibrium, one being a single nucleotide polymorphism in the $5^{\prime}$ promoter region at $-344(\mathrm{C}-\mathrm{T})$ that alters a putative regulation site for the transcription factor SF-1, and the other involving intron 2 of $C Y P 11 B 2$, which is partly replaced by the corresponding intron of CYP11B1. ${ }^{38}$ Recent studies have shown that the C$344 \mathrm{~T}$ polymorphism is associated with higher plasma and urinary aldosterone levels as well as elevated ARR among patients with hypertension. . $^{37,39,40}$ Interestingly, the $\mathrm{T}$ allele and intron 2 conversion of $C Y P 11 B 2$ are also associated with raised basal and ACTH-stimulated levels of the 11-deoxysteroids, DOC and deoxycortisol, which are converted to corticosterone and cortisol, respectively, by $11 \beta$-hyrdroxylase within the zona fasciculata. ${ }^{37}$ This evidence suggests that the T allele of CYP11B2 is associated with impaired activity of the enzyme $11 \beta$ hyrdroxylase which is encoded by the adjacent gene CYP11B1. Based on this evidence, Freel and Connell have hypothesized that $-344 \mathrm{~T}$ polymorphism of $C Y P 11 B 2$ may be in close linkage disequilibrium with a key quantitative trait locus in $C Y P 11 B 1$, adversely affecting its expression or function. ${ }^{37}$ Thus, individuals with less efficient cortisol synthesis, as a consequence of reduced $11 \beta$-hyrdroxylase activity, will maintain, through negative feedback regulation, a slightly enhanced ACTH drive to the adrenals, that in the long term is likely to cause hyperplasia of both zona fasciculata and zona glomerulosa of the adre- 
nal cortex, resulting in increased biosynthetic capacity for both cortisol and aldosterone.

\section{MONOGENIC FORMS OF LOW RENIN HYPERTENSION}

\section{Hypertensive forms of congenital adrenal hyperplasia $(\mathbf{C A H})$}

\section{1 $\beta$-hydroxylase deficiency}

This is a rare autosomal recessive disorder caused by mutations in the $C Y P 11 B 1$ gene. $.^{41} C Y P 11 B 1 \mathrm{mu}-$ tations result in reduced activity of $11 \beta$-hydroxylase, leading to low plasma cortisol, chronic elevation of ACTH and accumulation of the steroid precursors 11-deoxycortisol and deoxycorticosterone. Excessive DOC production exerts a net mineralocorticoid effect, leading to sodium retention, volume expansion and finally hypertension in approximately two thirds of untreated patients. ${ }^{41}$ Hypokalemia is variable, renin production is suppressed as a result of sodium retention and volume expansion, and aldosterone formation is low because of low plasma renin activity and low serum potassium concentrations.

\section{7a-hydroxylase deficiency}

This is a rare form of CAH caused by mutations of the CYP17 gene which is located on chromosome $10 \mathrm{q} 24 .{ }^{42}$ CYP 17 enzyme acts both as steroid $17 \alpha$-hydroxylase and as 17,20-lyase. Enzyme deficiency leads to diminished production of cortisol and sex steroids. Secondary elevation of ACTH causes an increased production of DOC and corticosterone with subsequent hypertension and hypokalemia. Aldosterone production is reduced as a result of suppressed renin.

\section{Apparent mineralocorticoid excess (AME)}

$\mathrm{AME}$ is a rare autosomal recessive disorder caused by deficiency of the $11 \beta$-hydroxysteroid dehydrogenase type $2(11 \beta-H S D 2)$ resulting from inactivating mutations of the $11 \beta-H S D 2$ gene. ${ }^{43,44}$ The $11 \beta$-HSD2 enzyme is co-expressed with the MR in renal tubular cells and converts cortisol to inactive cortisone, protecting the MR from saturation by cortisol and other glucocorticoids. ${ }^{45}$ Both aldosterone and cortisol bind to the MR so that the $11 \beta$ hydroxysteroid dehydrogenase system acts as a gate- keeper to prevent excessive activation of MR by high levels of cortisol. ${ }^{46}$ Defects in $11 \beta-H S D 2$ will lead to more cortisol being available to bind to the MR. Affected individuals have hypertension and hypokalemia, low renin and aldosterone levels and normal plasma cortisol levels, but the ratio of urinary free cortisol/free cortisone and/or of their metabolites (tetrahydrocortisol+allotetrahydrocortisol/tetrahydrocortisone) are elevated. ${ }^{47}$

\section{Constitutive activation of the mineralocorticoid receptor (Geller's syndrome)}

The inheritance pattern of this syndrome is autosomal-dominant. "Gain of function" mutations of the $M R$ gene located on chromosome 4q31 lead to the onset of hypertension that is markedly exacerbated in pregnancy. ${ }^{48}$

The ligand-binding domains of steroid hormone receptors are characterized by a conserved structure with 12 alpha-helices around a hydrophobic core. On agonist binding, a repositioned helix 12 forms a pocket with helix 3 (H3) and helix 5 (H5), where transcriptional coactivators bind. ${ }^{49} \mathrm{~A}$ mutation in the $M R$ gene results in the gain of a van der Waals interaction between helix 5 and helix 3 that substitutes for interaction of the steroid 21-hydroxyl group with helix 3 in the wild-type receptor. ${ }^{49}$ Consequently, H3-H5 interaction permits progesterone-mediated activation of the MR, functioning as a switch that regulates its activity. ${ }^{49,50}$ This mutation results in constitutive MR activity and alters receptor specificity, with classic MR antagonists like progesterone becoming potent agonists.

\section{Liddle's syndrome}

This is an autosomal dominantly inherited syndrome the main features of which include severe hypertension, hypokalemia, low plasma aldosterone levels and plasma renin activity. "Gain of function" mutations in the genes coding for the beta- or gamma-subunit of the renal epithelial sodium channel, located on chromosome 16p12, lead to constitutive activation of renal sodium reabsorption and subsequent volume expansion. Ten mutations causing Liddle's syndrome have been identified on the $S C N N 1 B$ gene and one on the SCNN1G gene. ${ }^{51-54}$ 


\section{Gordon's syndrome (pseudohypoaldosteronism type 2)}

Gordon's syndrome is an autosomal dominantly inherited disorder with defective genes, mapping to chromosomes 1,12 and $17 .{ }^{55}$ Recently, mutations have been identified in WNK kinases WNK1 and WNK4 on chromosomes 12 and 17, respectively. ${ }^{55}$ Abnormalities such as mutations in the amiloridesensitive sodium channel of the distal renal tubule are also accountable. Hypertension in these patients may develop as a consequence of increased renal $\mathrm{Na}$ reabsorption. Hyperkalemia follows reduced renal $\mathrm{K}^{+}$excretion despite normal glomerular filtration and aldosterone secretion. ${ }^{56}$ The reduced renal excretion of $\mathrm{K}^{+}$and consequent hyperkalemia causes this condition to resemble an aldosteronedeficient state (pseudohypoaldosteronism).

\section{GLUCOCORTICOID EXCESS - CUSHING'S SYNDROME}

Cushing's syndrome is usually due to excessive ACTH production from the pituitary gland, ectopic ACTH secretion by a non pituitary tumor, or excessive secretion of cortisol from an adrenocortical tumor. Hypertension is a major complication of hypercortisolemia but the underlying pathology is not fully defined. Several mechanisms of BP elevation have been proposed, including increased responsiveness to vasoconstrictors, decreased vasodilator production, increased hepatic production of angiotensinogen, increased cardiac output by glucocorticoids, reduced production of prostaglandins via inhibition of phospholipase A, increased insulin resistance and over-saturation of $11 \beta$-HSD activity. ${ }^{57}$

L-arginine is the substrate precursor of nitric oxide (NO), an endothelium-derived vasodilator implicated in animal models of cortisol-induced hypertension. NO is an inhibitor of platelet aggregation and adhesion, proliferation of VSMC and leukocyte adhesion to the endothelium. ${ }^{58,59}$ Glucocorticoids have a variety of effects on the NO system, including inhibition of NO synthase (NOS) isoforms and inhibition of transmembrane arginine transport. ${ }^{60}$ Glucocorticoid excess raises BP in association with abnormalities in the NO pathway in both animals and humans. ${ }^{61-63}$ L-arginine prevents and reverses the development of ACTH-induced hypertension in rats, ${ }^{64}$ but in humans cortisol induced hypertension has not so far been associated with abnormalities in the L-arginine metabolism..$^{57,62,64} \mathrm{Hu}$ man studies revealed that cortisol impairs acetylcholine induced vasodilation, as detected by using bilateral forearm plethysmography, and decreases NO metabolites. ${ }^{61}$ On the other hand, short-term cortisol infusions in volunteers did not alter biochemical or physiological markers of NO activity. ${ }^{65}$

In the past, it had been generally accepted that steroid hormones produce hypertension by acting through renal type I MRs to produce sodium and water retention. Recent studies are consistent with substantial dissociation between sodium retention and BP-raising effects of cortisol. ${ }^{66}$ Increase in cardiac output is not essential for the glucocorticoidinduced rise in BP, while the precise role of increases in peripheral resistance as a primary mechanism has not as yet been defined. Nevertheless, increased pressor responsiveness, particularly to catecholamines and Ang II, is a prominent feature. ${ }^{66}$ In vitro studies have shown that the number of AT1 receptors of VSMC is increased by glucocorticoids, whereas activity of depressor systems (i.e. the kallikreinkinin system, vasodilator prostaglandins and NO) is reduced. ${ }^{66}$

In addition, deficiency of $11 \beta-H S D$ may allow increased exposure of MR to glucocorticoids in extrarenal sites, particularly VSMC and heart. Moreover, endogenous renal $11 \beta$-HSD-inhibitory factor was significantly increased in patients with low-renin essential hypertension. ${ }^{67}$

The role of activation of classic type II glucocorticoid receptors (GRs) in cortisol-induced hypertension is unclear. There is evidence for the presence of GRs on endothelial cells and VSMC. ${ }^{68,69}$ Variations in the GR gene might contribute to essential hypertension; however, no evidence for an association of the GR gene locus in essential hypertension has been found, whilst the glucocorticoid antagonist RU-486 did not modify cortisol-induced elevations in BP. ${ }^{70,71}$ Nevertheless, Mulatero et al. found impaired binding of cortisol to the GR in hypertensives and decreased sensitivity to cortisol, while Walker et al. reported increased glucocorti- 
coid sensitivity in subjects at risk for hypertension and cardiovascular disease and in hypertensives. ${ }^{72,73}$ Effects of glucocorticoids on vascular resistance have been explained in part by an increased response of the vasculature to catecholamines and Ang II. ${ }^{66} \mathrm{Con}$ versely, other studies suggest that sympathetic activity is unaltered or reduced by cortisol and cortisol induced hypertension in humans is not a result of overactivity of the autonomic nervous system. According to this notion, ganglion blockade in human volunteers did not significantly alter BP in the pretreatment phase or on the last day of cortisol treatment. $^{74}$

Erythropoietin (EPO) is another candidate in the pathogenesis of glucocorticoid hypertension. EPO exerts direct vasoconstrictor effects in vitro and its concentrations correlate with BP in patients with essential hypertension. ${ }^{75} \mathrm{EPO}$-induced hypertension appears to be in part due to NO resistance. ${ }^{76}$ Cortisol increased both BP and serum EPO concentrations and there was a positive correlation between the change in systolic BP and the change in EPO concentration. It is possible that the rise in EPO concentration occurs as a consequence of some physiological effect of cortisol such as increased renal vascular resistance.

\section{Glucocorticoid resistance}

This autosomal recessive or dominantly inherited disorder is caused by inactivating mutations of the GR gene. ${ }^{77}$ Cortisol and ACTH are elevated without clinical features of Cushing's syndrome. Chronic ACTH rise can lead to stimulation of adrenal compounds with mineralocorticoid activity, and of cortisol which lead to stimulation of the MR, resulting in hypertension.

\section{CATECHOLAMINE EXCESS - PHEOCHROMOCYTOMA}

Pheochromocytoma is a rare neuroendocrine tumor composed of chromaffin-staining tissue that primarily secretes catecholamines but also neuropeptide Y (NPY). ${ }^{78}$ The clinical manifestations can vary depending on the type of catecholamines being produced and the amount and frequency of their release into the circulation. About $90 \%$ of pheochromocytomas are benign and $90 \%$ arise from the adrenal medulla, but they can also develop in extra-adrenal sympathetic/parasympathetic ganglia and in such cases they are referred to as paragangliomas. ${ }^{79}$

Classic symptoms include hypertension, headache, diaphoresis, perspiration, palpitations, tremor and tachycardia. The hypertension is caused by excessive plasma levels of catecholamines and may be sustained (20\%), sustained with paroxysms (50\%) or only paroxysmal $(25 \%)$.

Most pheochromocytomas are sporadic but $\sim 10 \%$ are familial.$^{80}$ Recent data suggest that germline mutations may be detected in up to $24 \%$ of unselected cases. ${ }^{81}$ Inherited predisposition to pheochromocytoma occurs in patients with multiple endocrine neoplasia type 2 (MEN 2), von HippelLindau disease (VHL), those with germline mutations in the $S D H B / C / D$ genes and less commonly in patients with neurofibromatosis type $1 .^{82}$

\section{Hereditary pheochromocytoma}

\section{Von Hippel-Lindau disease}

VHL disease is a dominantly inherited familial cancer syndrome with variable expression resulting from germline mutations in the VHL tumor suppressor gene ${ }^{83-85}$ VHL protein has been implicated in the regulation of hypoxia-inducible gene expression, mRNA stability, cell cycle control and control of extracellular fibronectin matrix assembly. ${ }^{86-88} \mathrm{VHL}$ inactivation results in upregulation of a wide range of hypoxia-inducible genes that promote angiogenesis and regulate glucose metabolism, apoptosis and matrix metabolism. ${ }^{89-91}$ The three major features of VHL disease are retinal and central nervous system hemangioblastomas and clear cell renal cell carcinoma and the lifetime risk for each of these tumors has been estimated as $>70 \% .{ }^{92}$ However, tumor specific risks are influenced by allelic heterogeneity and four phenotypic subclasses of VHL disease have been distinguished. In type 1 VHL, pheochromocytoma is absent and the most frequent manifestations are retinal and cerebellar hemangioblastomas and renal cell carcinoma (RCC). Type 2 VHL kindreds include individuals with pheochromocytoma with type $2 \mathrm{~B}$ being characterized by the 
development of pheochromocytoma, retinal and cerebellar hemangioblastomas and RCC, whereas in VHL type 2A, patients are at risk of pheochromocytoma, retinal and central nervous system hemangioblastomas but RCC is rare. Finally, type 2C VHL is characterized by the detection of germline VHL gene mutations in kindreds with a pheochromocytoma-only phenotype. ${ }^{92}$ The overall frequency of pheochromocytoma in VHL disease is $10-20 \%$, but it is very frequent in VHL type 2A and 2B kindreds, being the only feature in type $2 \mathrm{C}$ families and absent in type 1 . All $2 \mathrm{~A}$ and $2 \mathrm{C}$ types and the majority of $2 \mathrm{~B}$ type kindreds have missense mutations, whereas type 1 families share a greater proportion of germline mutations. ${ }^{93-96}$ Maher et al. estimated that, whereas the pheochromocytoma risk in patients with VHL gene deletions or truncating mutations is up to $5 \%$ at 50 years, this is increased 10 -fold in patients with missense mutations. ${ }^{96}$

\section{Succinate dehydrogenase mutations (SDH)}

Mitochondrial complex II is crucial for both the Krebs tricarboxylic acid cycle and the aerobic electron transport in mitochondria, and is composed of four subunits: SDH A, SDHB, SDHC and SDHD. The mechanism by which SDH subunit mutations predispose to pheochromocytomas is as yet unknown, but dysregulation of hypoxia-responsive genes and impairment of mitochondria-mediated apoptosis have been suggested.

Germline $S D H D$ and $S D H B$ mutations may cause pheochromocytoma susceptibility and are an important cause of familial and isolated pheochromocytoma. ${ }^{97,98}$ Germline mutations in SDHD were found in $V H L$ and RET mutation-negative familial pheochromocytoma. ${ }^{98,99}$ Moreover, in a study of non-familial, non-syndromic pheochromocytomas, up to $18 \%$ were found to harbor germline $S D H D$ mutations. ${ }^{97}$ Additionally, $S D H D, S D H B$ and $S D H C$ germline mutations were implicated in the genesis of hereditary paragangliomas and may be found in $\sim 20 \%$ of unselected patients. ${ }^{100-102}$ In another study, $S D H D$ and $S D H B$ germline mutations accounted for $70 \%$ of familial head and neck paragangliomas and $\sim 8 \%$ of apparently sporadic head and neck paragangliomas. ${ }^{103}$

\section{$M E N 2$}

MEN 2 is an autosomal dominantly inherited syndrome which is comprised of three clinical subtypes, MEN 2A, MEN 2B and familial medullary thyroid carcinoma MEN 2A. The most common clinical subtype is characterized by the classic triad of medullary thyroid carcinoma (MTC), pheochromocytoma and hyperparathyroidism. MEN 2B is less common and is characterized by MTC and pheochromocytoma. Approximately 50\% of MEN 2 patients develop pheochromocytoma and $\sim 95 \%$ of MEN 2 cases are caused by germline RET protooncogene mutations. ${ }^{104,105}$ Analyses on a referral series of MEN 2 suggested that germline mutations at $R E T$ codon 634 were associated with the development of pheochromocytoma. ${ }^{84,106}$

Glial cell line-derived neurotrophic factor (GDNF) is a recently identified natural ligand for RET and a good candidate for pheochromocytoma susceptibility. ${ }^{107,108}$ GDNF receptor-alpha seems to bind GDNF and subsequently is recognized by RET. This results in tyrosine phosphorylation of RET, leading to cell signaling. So far GDNF germline mutations do not appear to have a major role in the pathogenesis of familial or sporadic pheochromocytomas, whereas allelic variation at the GDNF locus may influence pheochromocytoma susceptibility. ${ }^{99}$

\section{Sporadic pheochromocytoma}

Somatic VHL mutations are infrequent $(<5 \%)$ in sporadic pheochromocytomas. ${ }^{109,110}$ Similarly, somatic RET mutations are found in $\sim 10 \%$ of sporadic pheochromocytomas suggesting that $V H L$ and $R E T$ are minor players in its pathogenesis. In addition, somatic $S D H B$ and $S D H D$ mutations do not play a major role in the pathogenesis of sporadic pheochromocytomas, nor do GDNF germline mutations. ${ }^{99}$ The involvement of additional genes in pheochromocytoma susceptibility is very likely, particularly in patients with extra-adrenal pheochromocytoma. In a study of 271 non-syndromic, nonfamilial pheochromocytomas, $24 \%$ were found to have a germline mutation in one of the VHL, RET, $S D H B$ or $S D H D$ genes. ${ }^{81,102,111-113}$

These data suggest that all patients with pheochromocytoma or paraganglioma should be subject- 
ed to genetic testing for these four genes. Mutation analysis should begin with $V H L$, although the presence of extra-adrenal disease might prompt commencement with $S D H D$.

\section{Mechanisms of hypertension in pheochromocytoma}

Hypertension in pheochromocytoma is a result of noradrenaline and NPY excessive secretion. Catecholamines stimulate the adrenergic system receptors resulting in their activation with subsequent increase in the vascular tone and accentuation of the VSMC response to pressor events. Elevation of BP has generally been attributed to effects of catecholamines despite the fact that many patients are under adrenergic blockade.

NPY is a neurohormone colocalized with catecholamines in the adrenal medulla and the NPY1 receptor is the major vascular receptor which mediates non-adrenergic vasoconstriction and vascular growth promoting activity. ${ }^{114}$ Although the action of catecholamines in pheochromocytoma related hypertension is of primary importance, studies have suggested that plasma levels of NPY are elevated in about $50-80 \%$ of patients with pheochromocytoma, this being within the range which is vasoconstrictive in humans. ${ }^{115}$ Some studies suggest that NPY is exclusively secreted together with adrenaline from the adrenaline-producing cells, while others report that it can be released together with both noradrenaline and adrenaline during the activation of the adrenal medulla. ${ }^{116,117}$ NPY may also be related to growth of pheochromocytoma due to the induction of vascular growth. ${ }^{118}$

\section{GROWTH HORMONE (GH) EXCESS - ACROMEGALY}

Acromegaly is caused by GH hypersecretion mostly due to a benign pituitary adenoma. GH operates in periphery through IGF-1 which is produced in different tissues. Both GH and IGF-1 modulate the expression of various growth factors and their receptors in several tissues. The prevalence of hypertension in acromegalic patients is reported to be approximately $35 \%$ (18-60\% in different clinical studies). ${ }^{119-121}$

\section{Mechanisms of hypertension in acromegaly}

Surgical or medical therapy reduces GH levels and results in a concomitant BP fall, indicating an important association between $\mathrm{GH}$ and hypertension. ${ }^{122,123}$ On the other hand, there are studies reporting no difference in plasma $\mathrm{GH}$ levels between normotensive and hypertensive acromegalics and no correlation between BP and GH or IGF-1 levels. ${ }^{124,125}$ These findings indicate that the exact pathogenetic mechanisms of hypertension in acromegaly are still unclear, although several mechanisms have been proposed (Figure 1).

In acromegaly, increased sodium retention associated with extracellular volume expansion may be due to the sodium retaining effect of GH. ${ }^{126} \mathrm{Ex}-$ perimental and clinical studies suggest an inhibitory action of GH on atrial natriuretic peptide (ANP) release which could contribute to reduced natriuresis. ${ }^{127} \mathrm{GH}$, IGF-1 and IGF-1R expression in the kidney and direct activation of distal tubular sodium channels by IGF-1 could account for this effect. ${ }^{128}$ $\mathrm{GH}$ administration increases glomerular filtration rate and renal plasma flow, an effect mediated probably via IGF-1. ${ }^{128}$ IGF-1 is also reported to lower $\mathrm{NH}_{2}$ terminal proANP and urinary sodium excretion. ${ }^{129}$

Acromegaly is often associated with insulin resistance, diabetes mellitus (DM) and hyperinsulinemia. GH excess stimulates lipolysis and glucose production and reduces glucose utilization. A rise in plasma insulin levels may induce hypertension by stimulating renal sodium absorption and sympathetic nervous activity. ${ }^{130}$ In addition, insulin stimulates vascular RAAS and growth of VSMC, while insulin resistance is associated with impaired NO production and vasodilation. Hyperinsulinemic patients with acromegaly have higher BP and hypertensive patients show higher insulin resistance after oral glucose tolerance load (OGTT) than normotensives. ${ }^{125}$

GH and IGF-1 may be involved in hypertension as a result of their growth-promoting action and effects on vascular tone. IGF-1 is an important mitogen expressed in endothelium and VSMC and stimulates angiotensinogen production in cultured VSMC. ${ }^{131} \mathrm{GH}$, either directly or via IGF-1, could 


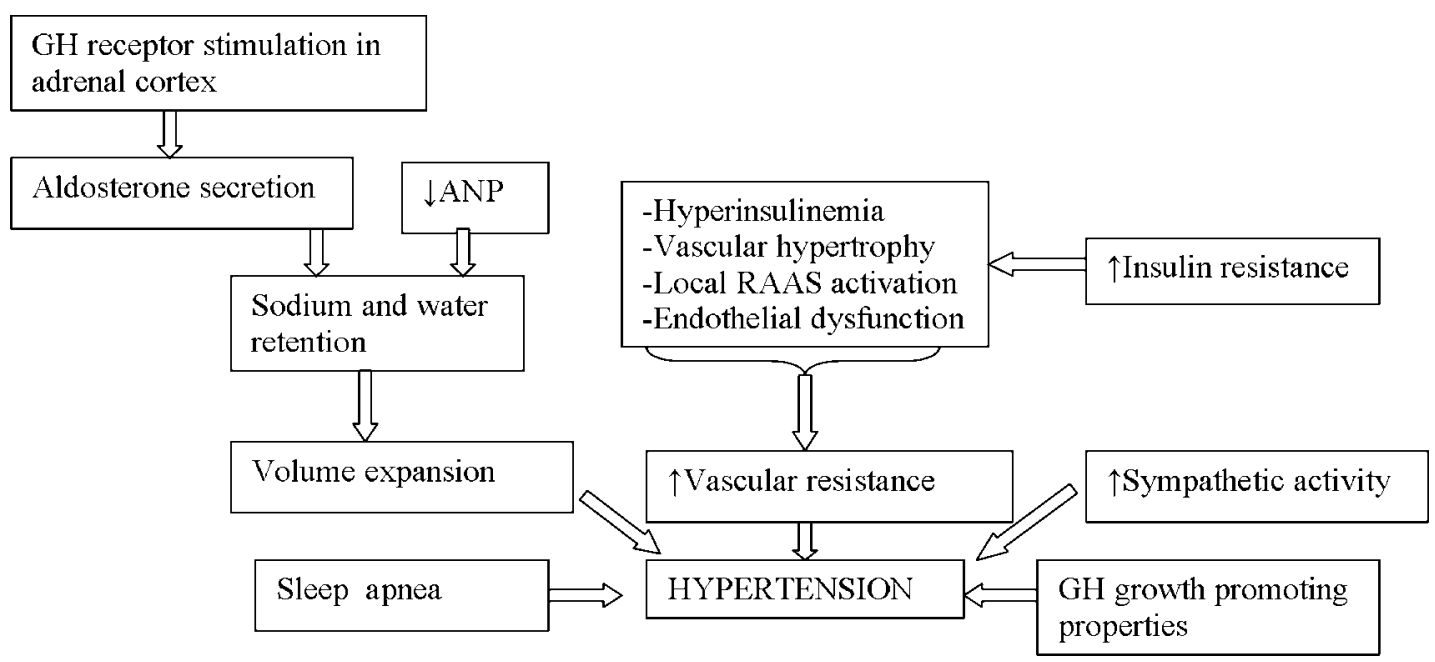

Figure 1. Mechanisms of GH induced hypertension in acromegaly. ANP, atrial natriuretic peptide; RAAS, renin angiotensin aldosterone system.

increase myocardial hypertrophy and contractility in animal models. ${ }^{132,133}$

The presence of GH receptors in human adrenal cortex raises the possibility of a direct $\mathrm{GH}$ effect on aldosterone secretion. ${ }^{134}$ Indeed, patients with acromegaly on sodium restriction have reduced aldosterone responsiveness and increased BP response to Ang II compared to controls. Nevertheless, other studies state that aldosterone levels are within normal limits. ${ }^{135,136}$

Finally, sleep apnea is associated with hypertension in the general population. ${ }^{137}$ It occurs in $60-75 \%$ of patients with acromegaly and may decrease the physiologic nocturnal fall in the BP. ${ }^{138}$ It is also associated with increased urinary metabolites of catecholamines, suggesting an increased sympathoadrenergic activity in hypertensives. ${ }^{139}$

\section{PRIMARY HYPERPARATHYROIDISM (PHPT)}

PHPT is caused by excessive secretion of parathyroid hormone (PTH), usually due to a single solitary parathyroid adenoma $(\sim 80 \%)$ or less commonly diffuse hyperplasia. PTH oversecretion causes hypercalcemia associated with an increased incidence of hypertension. The cause as well as the question of reversibility after parathyroid removal are controversial. Significantly higher aortic BP is found in patients with mild PHTP compared to a control group. ${ }^{140}$ However, others find no differences in central BP. ${ }^{141}$ PHPT is also associated with disturbances in the RAAS, whereas contradictory results exist as to whether structural and functional alterations in the vasculature are associated with PHPT. $^{142-145}$

\section{Mechanisms of hypertension in PHPT}

Potential mechanisms producing hypertension in PHPT include increased blood calcium levels, elevated intracellular calcium, increased $\mathrm{PTH}$, raised plasma renin activity, hypomagnesemia and glucose abnormalities.

An increased prevalence of cardiac structural abnormalities, such as left ventricular hypertrophy (LVH), has been observed in PHPT. ${ }^{146,147}$ It has been suggested that LVH in PTHP may be augmented by increased arterial pressure though others do not support this. ${ }^{141,147}$ PTH can act as a vasodilator stimulating VSMC and reducing the influx of calcium. ${ }^{148,149}$ Despite these properties, PTH infusion in man has produced contradictory results with regard to $\mathrm{BP}$ response.

Endothelium could be a target organ for PTH since PTH receptors were found on rat vascular endothelial cells. ${ }^{150}$ Human studies also report that increasing endothelial dysfunction is correlated with high PTH levels independently of calcium. ${ }^{151}$ Hypercalcemia induced by calcium infusion in healthy sub- 
jects has also been reported to impair endothelial vasodilatory function and increase systolic BP. ${ }^{152}$

Abnormal glucose metabolism, insulin resistance, high prevalence of DM and impaired glucose tolerance (IGT) have been reported in PHPT patients. ${ }^{153}$ Insulin resistance is associated with endothelial dysfunction which may contribute to the development of hypertension. ${ }^{154}$

Hypomagnesemia can potentiate the contractile activity of a variety of neurohumoral substances and induce vasospasm. Mean serum magnesium was found lower in hypertensive patients with surgically proven PHPT compared to normotensive patients, thus linking hypomagnesemia and hypertension. ${ }^{155}$

Parathyroid hypertensive factor (PHF) is a substance of parathyroid origin elevated in $30-40 \%$ of hypertensive patients. It may contribute to hypertension by potentiating the intracellular calciumraising effects of vasoconstrictors. $1,25-(\mathrm{OH})_{2} \mathrm{D}_{3}$ seems to stimulate PHF release, thereby playing a role in $\mathrm{BP}$ regulation. ${ }^{156}$

\section{THYROID HORMONE EXCESS}

Graves' disease has an estimated incidence of approximately $0.05 \%$ in the United States of America, according to the National Women's Health Information Central (NWHIC). Hyperthyroidism is accompanied by systolic hypertension in up to one third of patients. This results in part from the inability of the vascular system to accommodate the increase in stroke volume. Diastolic hypertension is uncommon in hyperthyroidism because of the fall in systemic vascular resistance (SVR). ${ }^{157}$ Treatment of the hyperthyroidism leads to a complete reversal of these changes in most patients. ${ }^{157}$

In animal models thyroid hormones have a positive inotropic effect by favoring fast myosin heavy chain-alpha synthesis, prolonging the inactivation of the $\mathrm{Na}^{+}$channels in cardiomyocytes, enhancing the intracellular uptake of $\mathrm{Na}^{+}$and the secondary activation of the myocardial sarcolemmal $\mathrm{Na}^{+}-\mathrm{Ca}^{2+}$ exchange and increasing calcium-adenosine triphosphatase and cAMP levels, together with an increase in the number and sensitivity of $\beta$-adrenergic receptors. ${ }^{158}$ Thyroid hormones therefore enhance calci- um entry into cardiomyocytes,${ }^{159}$ thus improving myocardial contractility.

Thyroid hormones exert a direct effect on the heart and vasculature, increasing the heart rate, blood volume, left ventricular stroke volume, ejection fraction and cardiac output. Thyroid hormones can increase sympathetic system activity and angiotensinogen levels and decrease vasopressin levels. ${ }^{160}$

$\mathrm{T}_{3}$ has a vasodilatory effect on arterioles. ${ }^{161} \mathrm{Va}$ sodilation results in a decrease in SVR followed by an increase in heart rate, a selective increase in blood flow to certain organs such as skeletal muscles and heart and a drop in diastolic BP. Vasodilation and the lack of rise in renal blood flow cause a decrease in renal perfusion pressure. The increase in renin release secondary to the hormone-dependent decrease in SVR may stimulate the angiotensin-aldosterone axis, thus increasing sodium reabsorption and blood volume. ${ }^{160}$ This contributes to an increase of preload, while the drop in SVR and the improved myocardial contractility result in a smaller afterload. The net effect translates into a significant increase in ventricular stroke volume which, when combined with the rise in heart rate, causes an increase in cardiac output (Figure 2).

\section{THYROID HORMONE DEFICIENCY}

Hashimoto's thyroiditis has an incidence estimate of about $0.5 \%$ in the United States according to NWHIC. Chronic hypothyroidism is frequently accompanied by cardiac dysfunction, increased vascular resistance and a greater prevalence of hypertension. ${ }^{160-162}$ Thyroid hormones can act as vasodilators on skeletal muscle in animal models ${ }^{161}$ and share the ability of regulating SVR by changes in VSMC contractility. Patients with hypertension and hypothyroidism have increased aortic stiffness which is decreased in most patients along with BP after treatment. ${ }^{162}$ Additionally, the induction of hypothyroidism by radioiodine therapy significantly increased diastolic BP, whereas restoration of euthyroidism reduced both systolic and diastolic BP. ${ }^{163}$

Thyroid hormone deficiency may be associated with a reduction of the glomerular filtration rate and renal blood flow. ${ }^{160}$ Cardiac output is reduced and 


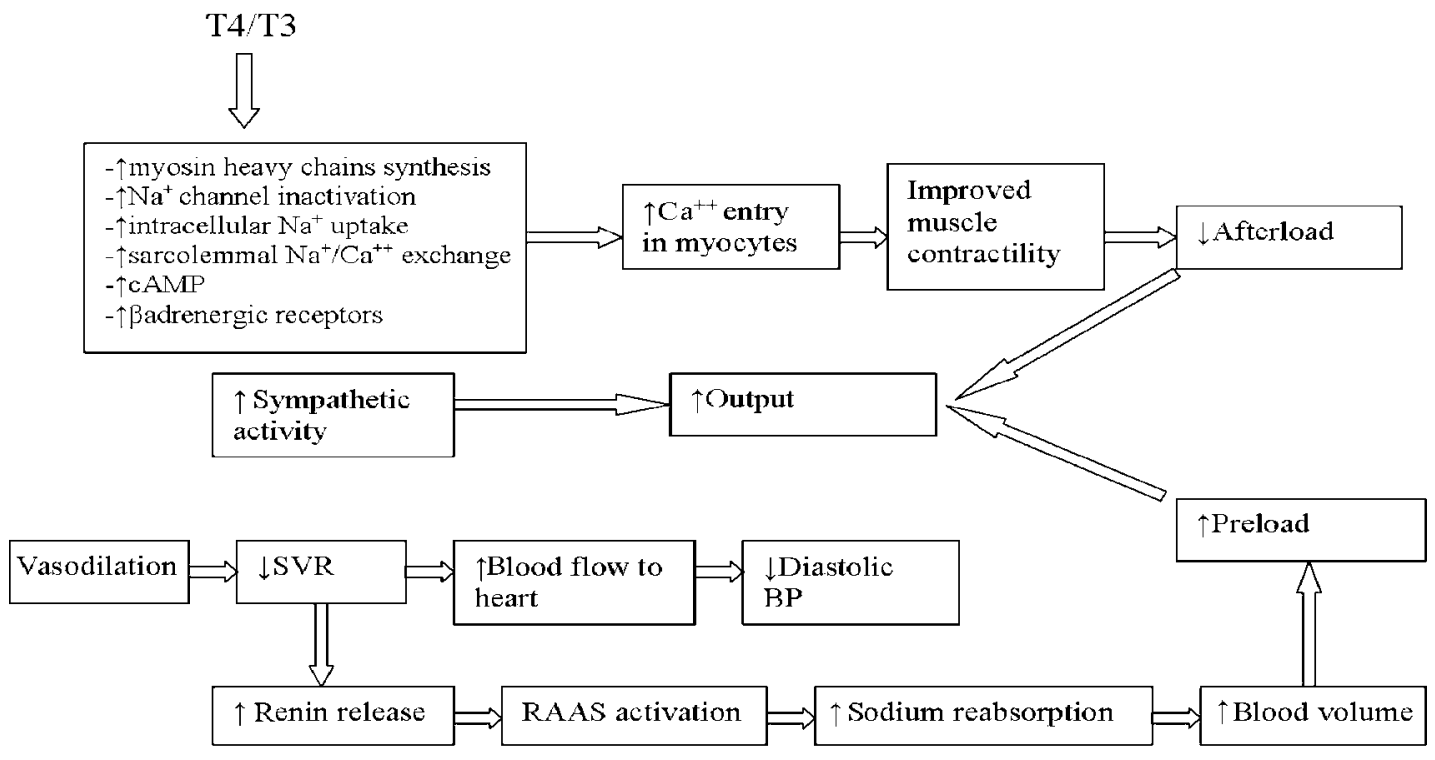

Figure 2. Thyroid hormones action on the heart and the vasculature. Abbreviations: RAAS, renin angiotensin aldosterone system; SVR, systemic vascular resistance; BP, blood pressure.

total peripheral resistance is elevated, probably as a result of increased sympathetic nervous tone and alpha-adrenergic response. There is also a tendency to increased diastolic BP as a result of increased SVR. ${ }^{164}$ Hypothyroid patients, even those with subclinical hypothyroidism, have impaired endothelial function, normal/depressed systolic function, left ventricular diastolic dysfunction at rest and systolic and diastolic dysfunction on exertion. ${ }^{164}$ All these abnormalities regress with L-T4 replacement therapy ${ }^{164}$ Hypothyroidism has also been associated with an increase in plasma norepinephrine and epinephrine, indicating a stimulatory effect on the sympathetic/adrenal systems, which contributes to hypertension and counteracts the decrease in myocardial inotropism and cardiac output. ${ }^{160}$ During hypothyroidism relatively higher levels of cortisol as well as aldosterone were observed. Recent studies have reported an increase in ACTH secretion in response to adrenal cortex dysfunction induced by acute hypothyroidism in experimental animals. ${ }^{165}$ Nevertheless, one cannot exclude the possibility that the increase in catecholamines, aldosterone and cortisol reflect, at least partially, a secondary response to reduced clearance or to decreased intravascular volume in hypothyroidism.

\section{CONCLUSIONS}

Secondary hypertension is a correctable form of hypertension. Endocrine hypertension has recently emerged as a very common cause of secondary hypertension, particularly after the recognition that PA is not as rare as formerly considered, encountered as it is in 5-15\% of hypertensives. Detailed medical history, thorough physical examination, appropriate laboratory tests and evaluation of risk factors can lead physicians to an early identification of endocrine hypertension, especially since affected individuals are often young. Understanding the pathophysiology of disorders causing endocrine hypertension will help us implement specific antihypertensive treatments and/or surgical interventions that could lead to the cure of hypertension.

\section{REFERENCES}

1. Lim PO, Rodgers P, Cardale K, Watson AD, Macdonald TM, 1999 Potentially high prevalence of primary aldosteronism in a primary care population. Lancet 353: 40.

2. Fardella CE, Mosso L, Gomez-Sanchez S, et al, 2000 Primary aldosteronism in essential hypertensives: prevalence, biochemical profile and molecular biology. J Clin Endocrinol Metab 85: 1863-1867. 
3. Hood S, Cannon J, Foo R, Brown M, 2005 Prevalence of primary hyperaldosteronism assesed by aldosterone to renin ratio and spironolactone testing: PHARST study. Clin Med 5: 55-60.

4. Schwartz GL, Chapman AB, Boerwinkle E, Kisabeth RM, Turner ST, 2002 Screeining for primary aldosteronism: implications of an increased plasma aldosterone/renin ratio. Clin Chem 48: 1919-1923.

5. Lim PO, Dow E, Brennan G, Jung RT, MacDonald TM, 2000 High prevalence of primary aldosteronism in the Tayside hypertension clinic population. J Hum Hypertens 14: 311-315.

6. Loh KC, Kony ES, Khaw MC, Emmanuel SC, Young WF Jr, 2000 Prevalence of primary aldosteronism among Asian hypertensive patients in Singapore. J Clin Endocrinol Metab 85: 2854-2859.

7. Lim PO, Struthers AD, MacDonald TM, 2002 The neurohormonal history of essential hypertension: Towards primary or tertiary aldosteronism? J Hypertension 20: 11-15.

8. Calhoun DA, Nishizaka MK, Zaman MA, Thakkar BB, Weissman P, 2002 Hyperaldosteronism among black and white subjects with resistant hypertension. Hypertension 40: 892-896.

9. Lifton RP, Dluhy RG, Powers M, et al, 1992 A chimeric $11 \beta$-hydroxylase/aldosterone synthase gene causes glucocorticoid-remediable aldosteronism and human hypertension. Nature 355: 262-265.

10. Litchfield WR, Coolidge C, Silva P, et al, 1997 Impaired potassium-stimulated aldosterone production: a possible explanation for normokalemic glucocorticoid-remediable aldosteronism. J Clin Endocrinol Metab 82: 1507-1510.

11. Stowasser M, Gordon RD, 2001 Familial hyperaldosteronism. J Steroid Biochem Mol Biol 78: 215-229.

12. Kawamoto T, Mitsuuchi Y, Toda K, et al, 1992 Role of steroid 11 beta-hydroxylase and steroid 18-hydroxylase in the biosynthesis of glucocorticoids and mineralocorticoids in humans. Proc Natl Acad Sci USA 89: 1458-1462.

13. Taymans SE, Pack S, Pak E, Torpy DJ, Zhuang Z, Stratakis CA, 1998 Human CYP11B2 aldosterone synthase maps to chromosome 8q24.3. J Clin Endocrinol Metab 83: 1033-1036.

14. Lifton RP, Dluhy RG, Powers M, et al, 1992 Hereditary hypertension caused by chimaeric gene duplications and ectopic expression of aldosterone synthase. Nature Genet 2: 66-74.

15. Gordon RD, Stowasser M, Tunny TJ, Klemm SA, Finn WL, Krek AL, 1991 Clinical and pathological diversity of primary aldosteronism including a new familial variety. Clin Exp Pharmacol Physiol 18: 283-286.

16. Mulatero P, Schiavone D Fallo F, et al, 2000 CYP11B2 gene polymorphisms in idiopathic hyperaldosteronism. Hypertension 35: 694-698.

17. Stowasser M, Gordon RD, 2000 Primary aldoster- onism: learning from the study of familial varieties. $\mathbf{J}$ Hypertens 18: 1165-1176.

18. Klemm SA, Ballantine DM, Tunny TJ, Stowasser M, Gordon RD, 1995 PCR-SSCP analysis of the angiotensin II type 1 receptor gene in patients with aldosterone-producing adenomas. Clin Exp Pharmacol Physiol 22: 457-459.

19. Ballantine DM, Klemm SA, Tunny TJ, Stowasser M, Gordon RD, 1996 PCR-SSCP analysis of the p53 gene in tumours of the adrenal gland. Clin Exp Pharmacol Physiol 23: 582-583.

20. Torpy DJ, Gordon RD, Lin JP, et al, 1998 Familial hyperaldosteronism type-II: description of a large kindred and exclusion of the aldosterone synthase CYP11B2 gene. J Clin Endocrinol Metab 83: 3214-3218.

21. Lafferty AR, Torpy DJ, Stowasser M, et al, 2000 A novel genetic locus for low renin hypertension: familial hyperaldosteronism type II maps to chromosome 7 7p22. J Med Genet 37: 831-835.

22. Elphinstone MS, Gordon RD, So A, Jeske YW, Stratakis CA, Stowasser M, 2004 Genomic structure of the human gene for protein kinase A regulatory subunit R1-beta (PRKAR1B) on 7p22: no evidence for mutations in familial hyperaldosteronism type II in a large affected kindred. Clin Endocrinol (Oxf) 61: 716723.

23. Pilon C, Mulatero P, Barzon L, et al, 1999 Mutations in $C Y P 11 B 1$ gene converting 11beta-hydroxylase into an aldosterone-producing enzyme are not present in aldosterone-producing adenomas. J Clin Endocrinol Metab 84: 4228-4231.

24. Higaki J, Miya A, Miki T, et al, 1991 Contribution of the activation of the ras oncogene to the evolution of aldosterone- and renin-secreting tumors. J Hypertens 9:135-137.

25. Zwermann O, Beuschlein F, Mora P, Weber G, Allolio B, Reincke M, 2000 Multiple endocrine neoplasia type 1 gene expression is normal in sporadic adrenocortical tumors. Eur J Endocrinol 142: 689-695.

26. Beuschlein F, Schulze E, Mora P, et al, 1998 Steroid 21-hydroxylase mutations and 21-hydroxylase messenger ribonucleic acid expression in human adrenocortical tumors. J Clin Endocrinol Metab 83: 2585-2588.

27. Fallo F, Pezzi V, Barzon L, et al, 2002 Quantitative assessment of $C Y P 11 B 1$ and $C Y P 11 B 2$ expression in aldosterone-producing adenomas. Eur J Endocrinol 147: 795-802.

28. Mulatero P, Veglio F, Pilon C, et al, 1998 Diagnosis of glucocorticoid-remediable aldosteronism in primary aldosteronism: aldosterone response to dexamethasone and long polymerase chain reaction for chimeric gene. J Clin Endocrinol Metab 83: 2573-2575.

29. Komesaroff P, Funder JW, Fuller PJ 1994 Mineralocorticoid resistance. In: Balliere's Clinical Endocrinology and Metabolism, Balliere Tindall, London; pp, 333355 . 
30. Horisberger JD, 1998 Amiloride sensitive Na channels. Curr Opin Cell Biol 10: 443-449.

31. Webster MK, Goya L, Ge Y, Maiyar AC, Firestone GL, 1993 Characterization of sgk, a novel member of the serine/threonine protein kinase gene family which is transcriptionally induced by glucocorticoids and serum. Mol Cell Biol 13: 2031-2040.

32. Naray-Fejes-Toth A, Canessa C, Cleaveland ES, Aldrich G, Fejes-Toth G, 1999 sgk is an aldosterone induced kinase in the renal collecting duct. Effects on epithelial Na channels. J Biol Chem 274: 16973-16978.

33. Rossi GP, Sacchetto A, Pavan E, et al, 1997 Remodeling of the left ventricle in primary aldosteronism due to Conn's adenoma. Circulation 95: 1471-1478.

34. Pitt B, Zannad F, Remme WJ, 1999 The effect of spironolactone on morbidity and mortality in patients with severe heart failure. N Engl J Med 341: 709-717.

35. Li JM, Shah AM, 2003 Mechanism of endothelial cell NADPH oxidase activation by angiotensin II. Role of the p47phox subunit. J Biol Chem 278: 12094-12100.

36. Wang CH, Li SH, Weisel RD, et al, 2003 C-reactive protein upregulates angiotensin type 1 receptors in vascular smooth muscle. Circulation 107: 1783-1790.

37. Freel EM, Connell JLC, 2004 Mechanisms of hypertension: the expanding role of aldosterone. J Am Soc Nephrol 15: 1993-2001.

38. White PC, Slutsker L, 1995 Haplotype analysis of CYP11B2 Endocr Res 21: 437-442.

39. Mulatero P, Schiavone D, Fallo F, et al, 2000 CYP11B2 gene polymorphisms in idiopathic hyperaldosteronism. Hypertension 35: 694-698.

40. Davies E, Kenyon CJ, 2003 CYP11B2 polymorphisms and cardiovascular risk factors. J Hypertens 21: 12491253.

41. Zachmann M, Tassinari D, Prader A, 1983 Clinical and biochemical variability of congenital adrenal hyperplasia due to 11beta-hydroxylase deficiency. J Endocrinol Metab 56: 222-229.

42. Fan YS, Sasi R, Lee C, Winter JSD, Waterman MR, Lin CC, 1992 Localization of the human CYP-17 gene cytochrome P45017a to 10q24.3 by florescence in situ binding and simultaneous chromosome banding. Genomics 14: 1110-1111.

43. Wilson RC, Krozowski ZS, Li K, et al, 1995 A mutation in the HSD11B2 gene in a family with apparent mineralocorticoid excess. J Clin Endocrinol Metab 80: 2263-2266.

44. Wilson RC, Dave-Sharma S, Wei JQ, et al, 1998 A genetic defect resulting in mild low-renin hypertension. Proc Natl Acad Sci USA 95: 10200-10205.

45. Stewart PM, Corrie JE, Shackleton CH, Edwards CR, 1988 Syndrome of apparent mineralocorticoid excess. A defect in the cortisol-cortisone shuttle. J Clin Invest 82: 340-349.

46. Edwards CR, Stewart PM, Burt D, et al, 1988 Localisation of 11-beta-hydroxysteroid dehydrogenase - tis- sue specific protector of the mineralocorticoid receptor. Lancet 2: 986-989.

47. Quinkler M, Oelkers W, Diederich S, 2000 In vivo measurement of renal 11beta-hydroxysteroid dehydrogenase type 2 activity. J Clin Endocrinol Metab 85: 4921-4922.

48. Geller DS, Farhi A, Pinkerton N, et al, 2000 Activating mineralocorticoid receptor mutation in hypertension exacerbated by pregnancy. Science 289: 119-123.

49. Zhang J, Sinisky J, Tsai FT, Geller DS, 2005 A critical role of helix 3-helix 5 interaction in steroid hormone receptor function. Proc Natl Acad Sci USA 102: $2707-$ 2712.

50. Geller DS, 2005 Mineralocorticoid resistance. Clin Endocrinol (Oxf) 62: 513-519.

51. Hiltunen TP, Hannila-Handelberg T, Petajaniemi N, et al, 2002 Liddle's syndrome associated with a point mutation in the extracellular domain of the epithelial sodium channel $\gamma$ subunit. J Hypertens 20: 2383-2390.

52. Uehara Y, Sasaguri M, Kinoshita A, et al, 1998 Genetic analysis of the epithelial sodium channel in Liddle's syndrome. J Hypertens 16: 1131-1135.

53. Tamura H, Schild L, Enomoto N, Matsui N, Marumo F, Rossier BC, 1996 Liddle disease caused by a missense mutation of $\beta$ subunit of the epithelial sodium channel gene. J Clin Invest 97: 1780-1784.

54. Hansson JH, Schild L, Lu Y, et al, 1995 A de novo missense mutation of the $\beta$ subunit of the epithelial sodium channel causes hypertension and Liddle syndrome, identifying a proline-rich segment critical for regulation of channel activity. Proc Natl Acad Sci USA 92: 11495-11499.

55. Wilson FH, Disse-Nicodeme S, Choate KA, et al, 2001 Human hypertension caused by mutations in WNK kinases. Science 293: 11-14.

56. Klemm SA, Gordon RD, Tunny TJ, Thompson RE, 1991 The syndrome of hypertension and hyperkalemia with normal GFR Gordon's syndrome: is there increased proximal sodium reabsorption? Clin Invest Med 14: 551-558.

57. Pirpiris M, Yeung S, Dewar E, et al, 1993 Hydrocortisone-induced hypertension in men. The role of cardiac output. Am J Hypertension 6: 287-294.

58. Arndt H, Smith CW, Granger DN, 1993 Leukocyteendothelial cell adhesion in spontaneously hypertensive and normotensive rats. Hypertension 21: 667-673.

59. Nakaki T, Nakayama M, Kato R, 1990 Inhibition by nitric oxide and nitric oxide-producing vasodilators of DNA synthesis in vascular smooth muscle cells. Eur J Pharmacol 189: 347-353.

60. Qiu C, Baylis C, 2000 Dexamethasone worsens nitric oxide inhibition-induced hypertension and renal dysfunction. Am J Hypertension 13: 1097-1102.

61. Kelly JJ, Tam SH, Williamson PM, Lawson J, Whitworth JA, 1998 The nitric oxide system and cortisolinduced hypertension in humans. Clin Exp Pharmacol 
Physiol 25: 945-946.

62. Wallerath T, Witte K, Schater SC, et al, 1999 Downregulation of the expression of endothelial NO synthase is likely to contribute to glucocorticoid-mediated hypertension. Proc Natl Acad Sci USA 96: 1335713362.

63. Huang PL, Huang ZH, Mashimo H, et al, 1995 Hypertension in mice lacking the gene for endothelial nitric oxide synthase. Nature 377: 239-242.

64. Turner SW, Wen C, Lim A, Whitworth JA, 1996 LArginine prevents corticotropin-induced increases in blood pressure in the rat. Hypertension 27: 184-189.

65. Williamson PM, Kohlagen JL, Mangos GJ, Whitworth JA, Kelly JJ, 2005 Acute effects of hydrocortisone on plasma nitrate/nitrite activity and foreman vasodilator responsiveness in normal human subjects. Clin Exp Pharmacol Physiol 32: 162-166.

66. Saruta T, 1996 Mechanism of glucocorticoid-induced hypertension. Hypertens Res 19: 1-8.

67. Takeda Y, Miyamori I, Iki K, et al, 1996 Endogenous renal 11 beta-hydroxysteroid dehydrogenase inhibitory factors in patients with low-renin essential hypertension. Hypertension 27: 197-201.

68. Ray KP, Farrow S, Daly M, Talabot F, Searle N, 1997 Induction of the E-selectin promoter by interleukin 1 and tumour necrosis factor alpha, and inhibition by glucocorticoids. Biochem J 328: 707-715.

69. Provencher PH, Saltis J, Funder JW, 1995 Glucocorticoids but not mineralocorticoids modulate endothelin-1 and angiotensin II binding in SHR vascular smooth muscle cells. J Steroid Biochem Mol Biol 52: 219-225.

70. Lin RCY, Wang WYS, Morris BJ, 1999 Association and linkage analyses of glucocorticoid receptor gene makers in essential hypertension. Hypertension 34: 1186-1192.

71. Clore JN, Estep H, Ross-Clunis JH, Watlington CO, 1988 Adrenocorticotrophin and cortisol-induced changes in urinary sodium and potassium excretion in man: effects of spironolactone and RU486. J Clin Endocrinol Metab 67: 824-831.

72. Mulatero P, Panarelli M, Schiavone D, et al, 1997 Impaired cortisol binding to glucocorticoid receptors in hypertensive patients. Hypertension 30: 1274-1278.

73. Walker BR, Phillips DIW, Noon JP, et al, 1998 Increased glucocorticoid activity in men with cardiovascular risk factors. Hypertension 31: 891-895.

74. Williamson PM, Tam SH, Kelly JJ, Whitworth JA, 2005 Ganglion blockade does not prevent cortisol-induced hypertension in man. Clin Exp Pharmacol Physiol 32: 294-296.

75. Kelly JJ, Martin A, Whitworth JA, 2000 Role of erythropoietin in cortisol induced hypertension. J Hum Hypertens 14:195-198.

76. Vaziri ND, Zhou XJ, Naqvi F, et al, 1996 Role of nitric oxide resistance in erythropoietin-induced hyper- tension in rats with chronic renal failure. Am J Physiol 271: E113-E122.

77. Kino T, Vottero A, Charmandari E, Chrousos GP, 2002 Familial/sporadic glucocorticoid resistance syndrome and hypertension. Ann NY Acad Sci 970: 101-111.

78. Koch CA, Vortmeyer AO, Zhuang Z, Brouwers FM, Pacak K, 2002 New insights into the genetics of familial chromaffin cell tumors. Ann NY Acad Sci 970: 11-28.

79. Lawrence JK, Maher ER, Sheaves R, Grossman AB, 2004 Familial paraganglioma: A novel presentation of a case and response to therapy with radiolabelled MIBG. Hormones 2: 127-131.

80. Anderson RJ, Lynch HT, 1993 Familial risk for neurendocrine tumours. Curr Opinion Oncol 5: 75-84.

81. Neumann HPH, Bausch B, McWhinney SR, et al, 2002 Germline mutations in nonsyndromic pheochromocytoma. N Engl J Med 346: 1486-1488.

82. Koch CA, Pacak K, Chrousos GP, 2002 The molecular pathogenesis of hereditary and sporadic adrenocortical and adrenomedullary tumors. J Clin Endocrinol Metab 87: 5367-5384.

83. Latif F, Tory K, Gnarra J, et al, 1993 Identification of the von Hippel-Lindau disease tumor suppressor gene. Science 260: 1317-1320.

84. Mulligan LM, Eng C, Healey CS, et al, 1994 Specific mutations of the RET proto-oncogene are related to disease phenotype in MEN 2A and FMTC. Nat Genet 6: 70-74.

85. Eng C, Clayton D, Schuffenecker I, et al, 1996 The relationship between specific RET proto-oncogene mutations and disease phenotype in multiple endocrine neoplasia type 2: International RET Mutation Consortium analysis. JAMA 276: 1575-1579.

86. Pause A, Lee S, Lonergan KM, Klausner RD 1998 The von Hippel-Lindau tumor suppressor gene is required for cell cycle exit upon serum withdrawal. Proc Natl Acad Sci USA 95: 993-998.

87. Ohh M, Yauch RL, Lonergan KM, et al, 1998 The von Hippel-Lindau tumor suppressor protein is required for proper assembly of an extracellular fibronectin matrix. Mol Cell 1: 959-968.

88. Pioli PA, Rigby W, 2001 The von Hippel-Lindau protein interacts with heteronuclear ribonucleoprotein a2 and regulates its expression. J Biol Chem 276: 4034640352.

89. Maxwell PH, Wiesener MS, Chang GW, 1999 The tumour suppressor protein VHL targets hypoxia-inducible factors for oxygen-dependent proteolysis. Nature 399: 271-275.

90. Cockman ME, Masson N, Mole DR, et al, $2000 \mathrm{Hy}-$ poxia-inducible factor- $\alpha$ binding and ubiquitylation by the von Hippel-Lindau tumor suppressor protein. J Biol Chem 275: 25733-25741.

91. Clifford SC, Cockman ME, Smallwood AC, et al, 2001 Contrasting effects on HIF-1a regulation by diseasecausing pVHL mutations correlate with patterns of 
tumourigenesis in von Hippel-Lindau disease. Hum Mol Genet 10: 1029-1038.

92. Maher ER, Jates JR, Harries R, et al, 1990 Clinical features and natural history of von Hippel-Lindau disease. Q J Med 77: 1151-1163.

93. Neumann HPH, Eng C, Mulligan LM, et al, 1995 Consequences of direct genetic testing for germ-line mutations in the clinical management of families with multiple endocrine neoplasia type 2. JAMA 274: 11491151.

94. Zbar B, Kishida T, Chen F, et al, 1996 Germline mutations in the von Hippel-Lindau disease (VHL) gene in families from North America, Europe and Japan. Hum Mutat 8: 348-357.

95. Webster AR, Richards FM, MacRonald FE, Moore AT, Maher ER, 1998 An analysis of phenotypic variation in the familial cancer syndrome von Hippel-Lindau disease: evidence for modifier effects. Am J Hum Genet 63: 1025-1035.

96. Maher ER, Webster AR, Richards FM, et al, 1996 Phenotypic expression in von Hippel-Lindau disease: correlations with germline $V H L$ mutations. J Med Genet 81: 328-332.

97. Gimm O, Armanios M, Dziema H, Neumann HPH, Eng C, 2000 Somatic and occult germline mutations in $S D H D$, a mitochondrial complex II gene, in non-familial pheochromocytomas. Cancer Res 60: 6822-6825.

98. Astuti D, Douglas F, Lennard TWJ, et al, 2001 Germline $S D H D$ mutation in familial phaeochromocytoma. Lancet 357: 1181-1182.

99. Woodward ER, Eng C, McMahon R, Affara NA, Ponder BAJ, Maher ER, 1997 Genetic predisposition to phaeochromocytoma: analysis of candidate genes GDNF, RET and VHL. Hum Mol Genet 6: 1051-1056.

100. Baysal BE, Ferrell RE, Willett-Brozick JE, et al, 2000 Mutations in $S D H D$, a mitochondrial complex II gene, in hereditary paraganglioma. Science 287: 848-851.

101. Astuti D, Latif F, Dallol A, et al, 2001 Mutations in the mitochondrial complex II subunit SDHB cause susceptibility to familial paraganglioma and pheochromocytoma. Am J Hum Genet 69: 49-54.

102. Niemann S, Muller U, 2000 Mutations in SDHC cause autosomal dominant paraganglioma. Nat Genet 26: 141-150.

103. Baysal BE, Willett-Brozick JE, Lawrence EC, et al, 2002 Prevalence of SDHB, SDHC and SDHD in clinic patients with head and neck paragangliomas. J Med Genet 39: 178-183.

104.Smith DP, Houghton C, Ponder BAJ, 1997 Germline mutation of RET codon 883 in two cases of de novo MEN 2B. Oncogene 15: 1213-1217.

105.Eng C, Smith DP, Mulligan LM, et al, 1995 A novel point mutation in the tyrosine kinase domain of the RET proto-oncogene in sporadic medullary thyroid carcinoma and in a family with FMTC. Oncogene 10: 509-513.
106. Schuffenecker I, Ginet N, Goldgar D, 1997 Prevalence and parental origin of de novo RET mutations in MEN 2A and FMTC. Am J Hum Genet 60: 233-237.

107.Trupp M, Arenas E, Fainzilber M, et al, 1996 Functional receptor for GDNF encoded by the c-ret protooncogene. Nature 381: 785-789.

108.Jing S, Wen D, Yu Y, 1996 GDNF-induced activation of the RET protein tyrosine kinase is mediated by GDNFR-alpha, a novel receptor for GDNF. Cell 85: 1113-1124.

109.Eng C, Crossey PA, Mulligan LM, et al, 1995 Mutations in the RET proto-oncogene and the von HippelLindau disease tumour suppressor gene in sporadic and syndromic phaeochromocytomas. J Med Genet 32: 934-937.

110. Hofstra RMW, Stelwagen T, Stulp RP, et al, 1996 Extensive mutation scanning of RET in sporadic medullary thyroid carcinoma and of RET and VHL in sporadic phaeochromocytomas reveals involvement of these genes in only a minority of cases. J Clin Endocrinol Metab 81: 2881-2884.

111. Maxwell, PH, Ratcliffe PJ, 2002 Oxygen sensors and angiogenesis. Semin Dev Biol 3: 29-37.

112. Niemann S, Muller U, 2000 Mutations in SDHC cause autosomal dominant paraganglioma. Nat Genet 26: 141-150.

113. Clifford SC, Maher ER, 2001 Von Hippel-Lindau disease: clinical and molecular perspectives. Adv Cancer Res 82: 85-105.

114. Pons J, Lee EW, Li L, Kitlinska J, 2004 Neuropeptide Y: multiple receptors and multiple roles in cardiovascular diseases. Curr Opin Investig Drugs 9: 957-962.

115. Pruszczyk P, Wocial B, Ignatowska-Switalska H, et al, 1995 Does plasma neuropeptide-Y immunoreactivity in patients with pheochromocytoma depend on hormonal activity of the tumor? Clin Chim Acta 243: 205212.

116. Lundberg JM, Hokfelt T, Ahensen T, et al, 1986 Neuropeptide $\mathrm{Y}$ immunoreactivity in adrenaline cells of adrenal medulla and in tumours and plasma pheochromocytoma patients. Regulat Peptides 13: 169-182.

117. Varndell JM, Polak JM, Allen JM, Terenghi G, Bloom SR, 1984 Neuropeptide tyrosine NPY immunoreactivity in norepinephrine-containing cells and nerves of the mammalian adrenal gland. Endocrinology 114: 1460-1462.

118. Kuch-Wocial A, Slubowska K, Kostrubiec M, 2004 Plasma neuropeptide Y immunoreactivity influences left ventricular mass in pheochromocytoma. Clin Chim Acta 345: 43-57.

119. Etxabe J, Gaztambide S, Latorre P, Vasquez JA, 1993 Acromegaly: an epidemiological study. J Endocrinol Invest 16: 181-187.

120. Rajasoorya C, Holdaway IM, Wrightson P, Scott DJ, Ibbertson HK, 1994 Determinants of clinical outcome and survival in acromegaly. Clin Endocrinol (Oxf) 41: 
95-102.

121. Melmed S, 2001 Acromegaly and cancer: not a problem. J Clin Endocrinol Metab 86: 2929-2934.

122. Minniti G, Moroni C, Jaffrain-Rea ML, et al, 2001 Marked improvement in cardiovascular function after successful transsphenoidal surgery in acromegalic patients. Clin Endocrinol (Oxf) 55: 307-313.

123. Colao A, Ferone D, Marzullo P, et al, 2001 Long-term effects of depot long-acting somatostatin analog octreotide on hormone levels and tumor mass in acromegaly. J Clin Endocrinol Metab 86: 2779-2786.

124. Ezzat S, Forster MJ, Berchtold P, Redelmeier DA, Boerlin V, Harris AG, 1994 Acromegaly. Clinical and biochemical features in 500 patients. Medicine Baltimore 73: 233-240.

125. Colao A, Baldelli R, Marzullo P, et al, 2000 Systemic hypertension and impaired glucose tolerance are independently correlated to the severity of the acromegalic cardiomyopathy. J Clin Endocrinol Metab 85: 193199.

126. Moller J, Nielsen S, Hansen TK, 1999 Growth hormone and fluid retention. Horm Res 51: Suppl 3: 116-120.

127. Moller J, Jorgensen JO, Moller N, Hansen KW, Pedersen EB, Christiansen JS, 1991 Expansion of extracellular volume and suppression of atrial natriuretic peptide after growth hormone administration in normal man. J Clin Endocrinol Metab 72: 768-772.

128. Feld S, Hirschberg R, 1996 Growth hormone, the insulin-like growth factor system, and the kidney. Endocr Rev 17: 423-480.

129. Moller J, Jorgensen JO, Marqversen J, Frandsen E, Christiansen JS, 2000 Insulin-like growth factor I administration induces fluid and sodium retention in healthy adults: possible involvement of renin and atrial natriuretic factor. Clin Endocrinol (Oxf ) 52: 181186.

130.Jaffrain-Rea ML, Moroni C, Baldelli R, et al, 2001 Relationship between blood pressure and glucose tolerance in acromegaly. Clin Endocrinol (Oxf) 54: 189195.

131. Kamide K, Hori MT, Zhu JH, et al, 2000 Insulin and insulin-like growth factor-I promotes angiotensinogen production and growth in vascular smooth muscle cells. J Hypertens 18: 1051-1056.

132. Lu C, Schwartzbauer G, Sperling MA, et al, 2001 Demonstration of direct effects of growth hormone on neonatal cardiomyocytes. J Biol Chem 276: 22892-22900.

133. Colao A, Marzullo P, Di Somma C, Lombardi G, 2001 Growth hormone and the heart. Clin Endocrinol Oxf 54: 137-154.

134. Lin CJ, Mendonca BB, Lucon AM, Guazzelli IC, Nicolau W, Villares SM, 1997 Growth hormone receptor messenger ribonucleic acid in normal and pathologic human adrenocortical tissues - an analysis by quantitative polymerase chain reaction technique. J Clin Endocrinol Metab 82: 2671-2676.
135. Ohtsuka H, Komiya I, Aizawa T, Yamada T, 1995 Hypertension in acromegaly: hereditary hypertensive factor produces hypertension by enhancing IGF-I production. Endocr J 42: 781-787.

136. Deray G, Chanson P, Maistre G, et al, 1990 Atrial natriuretic factor in patients with acromegaly. Eur J Clin Pharmacol 38: 409-413.

137. Lavie P, Herer P, Hoffstein V, 2000 Obstructive sleep apnoea syndrome as a risk factor for hypertension: population study. BMJ 320: 479-482.

138. Lanfranchi P, Somers VK, 2001 Obstructive sleep apnea and vascular disease. Respir Res 2: 315-319.

139. Elmasry A, Lindberg E, Hedner J, Janson C, Boman G, 2002 Obstructive sleep apnoea and urine catecholamines in hypertensive males: a population-based study. Eur Respir J 19: 511-517.

140. Smith JC, Page MD, John R, et al, 2000 Augmentation of central arterial pressure in mild primary hyperparathyroidism. J Clin Endocrinol Metab 85: 35153519.

141. Kosch M, Hausberg M, Barenbrock M, et al, 2001 Arterial distensibility and pulse wave velocity in patients with primary hyperparathyroidism before and after parathyroidectomy. Clin Nephrol 55: 303-308.

142. Kovacs L, Goth MI, Szabolcs I, et al, 1998 The effect of surgical treatment on secondary hyperaldosteronism and the relative hyperinsulinemia in primary hyperparathyroidism. Eur J Endocrinol 138: 543-547.

143. Nuzzo V, Tauchmanova L, Fonderico F, et al, 2002 Increased intima-media thickness of the carotid artery wall, normal blood pressure profile and normal left ventricular mass in subjects with primary hyperparathyroidism. Eur J Endocrinol 147: 453-459.

144. Kosch M, Hausberg M, Vormbrock K, et al, 2000 Studies on flow-mediated vasodilation and intima-media thickness of the brachial artery in patients with primary hyperparathyroidism. Am J Hypertens 13: 759-76.4

145. Neunteufl T, Katzenschlager R, Abela C, et al, 1998 Impairment of endothelium-independent vasodilation in patients with hypercalcemia. Cardiovasc Res 40: 396401.

146. Piovesan A, Molineri N, Casasso F, et al, 1999 Left ventricular hypertrophy in primary hyperparathyroidism. Effects of successful parathyroidectomy. Clin Endocrinol (Oxf) 50: 321-328.

147.Stefenelli T, Abela C, Frank H, et al, 1997 Cardiac abnormalities in patients with primary hyperparathyroidism: implications for follow-up. J Clin Endocrinol Metab 82: 106-112.

148. Hanson AS, Linas SL, 1994 Parathyroid hormone/adenylate cyclase coupling in vascular smooth muscle cells. Hypertension 23: 468-475.

149. Wang R, Wu L, Karpinski E, et al, 1991 The effects of parathyroid hormone on L-type voltage-dependent calcium channel currents in vascular smooth muscle cells and ventricular myocytes are mediated by a cyclic 
AMP dependent mechanism FEBS Lett 282: 331-334. 150.Jiang B, Morimoto S, Yang J, Niinoabu T, Fukuo K, OgBIHra T, 1998 Expression of parathyroid hormone/ parathyroid hormone-related protein receptor in vascular endothelial cells. J Cardiovasc Pharmacol 31: Suppl 1: 142-144.

151. Barenbrock M, Hausberg M, Kosch M, Kisters K, Hoeks AP, Rahn KH, 1998 Effect of hyperparathyroidism on arterial distensibility in renal transplant recipients. Kidney Int 54: 210-215.

152. Nilsson IL, Rastad J, Johansson K, Lind L, 2001 Endothelial vasodilatory function and blood pressure response to local and systemic hypercalcemia. Surgery 130: 986-990.

153. Procopio M, Magro G, Cesario F, et al, 2002 The oral glucose tolerance test reveals a high frequency of both impaired glucose tolerance and undiagnosed Type 2 diabetes mellitus in primary hyperparathyroidism. Diabet Med 19: 958-961.

154. Scherrer U, Sartori C, 2000 Defective nitric oxide synthesis: a link between metabolic insulin resistance, sympathetic overactivity and cardiovascular morbidity. Eur J Endocrinol 142: 315-323.

155. Sangal AK, Kevwitch M, Rao DS, Rival J, 1989 Hypomagnesemia and hypertension in primary hyperparathyroidism. South Med J 82: 1116-1118.

156. Jespersen B, Randlov A, Abrahamsen J, Fogh-Andersen N, Olsen NV, Kanstrup IL, 1998 Acute cardiovascular effect of 1,25-dihydroxycholecalciferol in essential hypertension. Am J Hypertens 11: 659-666.
157. Saito I, Saruta T, 1994 Hypertension in thyroid disorders. Endocrinol Metab Clin North Am 23: 379-386.

158. Dilmann WH, 1990 Biochemical basis of thyroid hormone action in the heart. Am J Med 88: 626-630.

159. Walker JD, Crawford FA Jr, Mukherjee R, Spinale FG, 1995 The direct effects of 3,5,3'-triiodo-L-thyronine $\mathrm{T} 3$ on myocyte contractile processes. Insights into mechanisms of action. J Thorac Cardiovasc Surg 110: 1369-1379.

160. Fomei E, Iervasi G, 2002 The role of thyroid hormone in blood pressure homeostasis: Evidence from shortterm hypothyroidism in humans. J Clin Endocrinol Metab 87: 1996-2000.

161. Ojamaa K, Klemperer JD, Klein I, 1996 Acute effects of thyroid hormone on vascular smooth muscle. Thyroid 6: 505-512.

162.Dernellis J, Panaretou M, 2002 Effects of thyroid replacement therapy on arterial blood pressure in patients with hypertension and hypothyroidism. Am Heart J 143: 718-724.

163. Streeten DH, Anderson GH Jr, Howland T, Chiang R, Smulyan H, 1998 Effects of thyroid function on blood pressure. Recognition of hypothyroid hypertension. Hypertension 11: 78-83.

164. Biondi B, Klein I, 2004 Hypothyroidism as a risk factor for cardiovascular disease. Endocrine 24: 1-13.

165. Tohei A, Watanabe G, Toya K, 1998 Hypersecretion of corticotrophin-releasing hormone and arginine vasopressin in hypothyroid male rats as estimated with push-pull perfusion. J Endocrinol 156: 395-400. 